\title{
IIIIII nordon
}

\section{Norræn samstarfsáætlun um stefnu í nýsköpun og atvinnulífi 2014-2017}

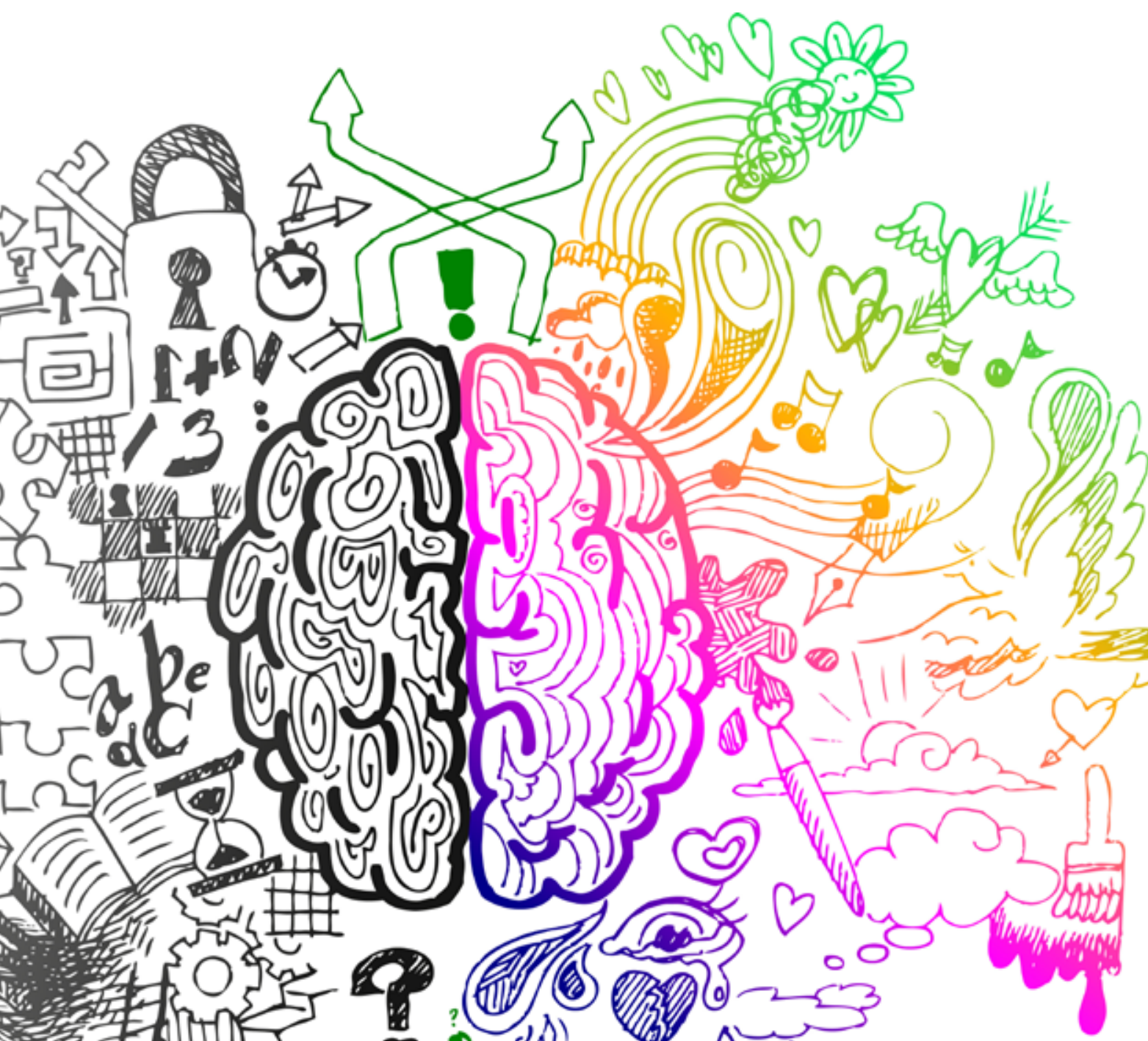


Norræn samstarfsáætlun um stefnu i nýsköpun og

atvinnulífi 2014-2017

ISBN 978-92-893-2741-1

http://dx.doi.org/10.6027/ANP2014-724

ANP 2014:724

C Norræna rádherranefndin 2014

Umbrot: Jette Koefoed

Kápumynd: ImageSelect

Ljósmynd: Image Select

Leturgerd: Meta LF

www.norden.org/is/utgafa

\section{Norrænt samstarf}

Norræna samstarfið er eitt umfangsmesta svæðasamstarf í heiminum.

Samstarfið nær til Danmerkur, Finnlands, Íslands, Noregs og Svípjódar auk Álandseyja, Færeyja og Grænlands.

Norræna samstarfið er pólitískt, efnahagslegt og menningarlegt og skiptir miklu í evrópsku og alpjódlegu samstarfi. Í norrænu samstarfi er unnið að pví að styrkja stöðu Norðurlanda í sterkri Evrópu.

Með norrænu samstarfi er unnið að pví að efla norræna og svæðisbundna

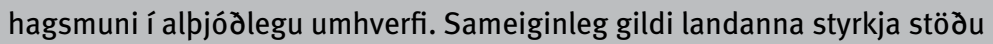
Norðurlanda og skipa peim meðal peirra svæða í heiminum par sem nýsköpun og samkeppnishæfni er mest.

\section{Norræna ráðherranefndin}

Ved Stranden 18

DK-1061 København K

Phone (+45) 33960200

www.norden.org 


\section{Norræn samstarfsáætlun um stefnu í nýsköpun og atvinnulífi 2014-2017}

Ad takast á vid áskoranir framtídarinnar 5

Áherslur í samstarfinu 2014-2017 9

Pemu og kyndilverkefni 10

Frumkvödlastarf og fjármögnun 10

$\begin{array}{ll}\text { Grænn hagvöxtur } & 12\end{array}$

Nýjar velferðarlausnir $\quad 14$

Menning og sköpun í págu hagvaxtar 16

Framkvæmd, fjármögnun og eftirfylgni kyndilverkefnanna 18 


\section{Formáli}

Norrænu pjódirnar hafa lengi unnið saman. Samstarfið byggir á sameiginlegum gildum og ósk um ad̀ ná árangri sem stuðlar ad öflugri próun svæðisins. Meðal markmiðanna er að eftirsóknarvert verði að búa, starfa og reka fyrirtæki á Norðurlöndum og ad efla samkeppnishæfni norrænu ríkjanna á alpjódavettvangi.

Leiðarljós norrænu samstarfsáætlunarinnar um stefnumótun í nýsköpun og atvinnulífi er að reyna að takast á við nokkur af peim verkefnum sem blasa við Norðurlöndum í framtídinni.

Framtídarsýnin er: Framtíd med sjálfbærum vexti á Norðurlöndum.

Samstarf norrænu ríkjanna getur skilad miklum hagvexti. Á næstu fjórum árum, 2014-2017, mun samstarfsáætlunin einskorðast við fjögur áherslusvið:

Frumkvödlastarfog fjármögnun med áherslu á að efla kunnáttu á sviði frumkvöðlastarfs og audvelda adgang ad fjármögnun á byrjunarstigum og að koma Norðurlöndum i fremstu röða á sviði nýrra og nýskapandi stafrænna lausna.
Grænn hagvöxtur á að styrkja stöðu Norðurlanda í fremstu rödá sviði nýsköpunar hvad varðar loftslagsvænar lausnir og grænan hagvöxt.

Ný velferðarúrræði eiga að styrkja stöðu Norðurlanda sem nýskapandi svædis í fremstu röd á sviði heilsu og velferðar.

Menning og skapandi greinar í págu hagvaxtar med áherslu á ad efla samkeppnishæfni menningartengdra og skapandi greina á Norðurlöndum og stuðla

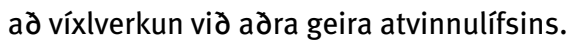

Samstarfsáætlunin á à leiða til verkefna sem skapa virðisauka vegna pess à pau eru framkvæmd á norrænum grundvelli en ekki einungis í hverju landi fyrir sig. Í sameiningu getum við orðið sterkari heild og fengið aukið vægi á alpjódavettvangi.

Fyrir hönd atvinnumálarádherra Norðurlanda

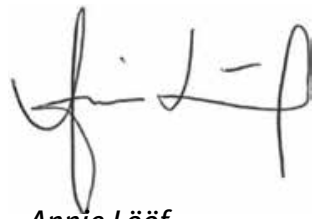

Annie Lööf

atvinnumálarádherra

Svípjód 


\section{Ad takast á við áskoranir framtídarinnar}

\begin{abstract}
Við Norðurlandabúar stöndum frammi fyrir ýmsum samfélagslegum áskorunum, meðal annars í umhverfis-, orku- og heilbrigðismálum og í tengslum við hækkandi medalaldur. Pessar áskoranir eru pverfaglegar og pví getur verì pörfá samstarfi milli mismunandi samfélagsgeira og fagsvida og milli landa. Áskoranirnar fela í sér hvatningu til ad finna nýjar, sjálfbærar lausnir sem sídan geta falid í sér ný tækifæri, hvort tveggja fyrir frumkvöəla og fyrirtæki og fyrir opinbera adila.
\end{abstract}

\section{Umheimurinn tekur breytingum}

Helsta áskorun okkar tíma er að búa til sjálfbæran hagvöxt sem skilar gódri og skilvirkri samfélagspjónustu pannig að velferðarstigið haldist hátt. Pessu parf að áorka í alpjódlegu hagkerfi sem tekur sífellt hradari breytingum. Sterkar efnahagslegar miðstöðvar í Evrópu og Norður-Ameríku purfa að takast á við nýja landfræðilega skipan efnahagslífsins par sem fjöldi markada, einkum í Asíu og SudurAmeríku, verda sífellt öflugri og hafa aukin áhrif á hnattræna próun. Jafnframt eru ad verda verulegar pólitískar og efnahagslegar breytingar í Afríku.

Framleiðsla á vörum og pjónustu er nú á dögum samtengd í pessari alpjódlegu samkeppni. Umskiptin frá alpjódlegu hagkerfi sem byggist á verslun med tilbúnar vörur til hagkerfis sem í síauknum mæli byggir á hnattrænum virðiskeðjum hefur í för med sér ad svædi og fyrirtæki í ólíkum heimshlutum hafa meiri áhrif hvert á annad en ádur. Fjárfestingar og hagvöxtur mótast jafnframt í auknum mæli af pví à hagkerfi okkar byggja sífellt meira á pekkingu. Audlindin sem felst í pekkingu er mikilvægur drifkraftur próunar og hagvaxtar.

Pær miklu alpjódlegu breytingar sem kenndar eru við hnattvæðingu hafa haft mikil áhrif á Norðurlönd og breytt samkeppnisstödu peirra á alpjódavettvangi. Útilokad er ad gera sér fulla grein fyrir hvernig pessar breytingar sem hafa verid nefndar munu próast í framtídinni. Við vitum pó með vissu að alpjódleg samkeppni um markaði verður sífellt harðari.

\section{Aə̀ takast á viò framtíoina med nýsköpun og samstarfi}

Auknar kröfur verða gerdar til pess að atvinnulífid og samfélagið hafi getu til ad próast pannig að pað geti tekist á við pær

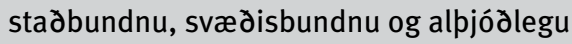
áskoranir sem við stöndum frammi fyrir. Til að ná árangri í pessum efnum verður 
nýsköpunin að vera í fyrirrúmi. Pað gildir bæði um einkageirann og opinbera geirann. Eftir pví sem okkur tekst betur að leiða saman mismunandi pekkingu og verkkunnáttu í pví skyni ad búa til nýjar vörur, nýja pjónustu, nýja ferla og nýjar skipulagslegar lausnir peim mun betur verðum við búin til að takast á við framtídina á Norðurlöndum, i Evrópu og á mörkuðum um allan heim.

Á vettvangi Evrópusambandsins og Efnahagsog framfarastofnunarinnar (OECD) er lögð áhersla á mikilvægi pess ad horfa á málin hvort tveggja frá sjónarhóli útboda og frá sjónarhóli eftirspurnar og láta heildarsýn á efnahaginn ráda ferðinni. pad pýdir ad pólitískar adgerðir á sviði nýsköpunar purfa að fara fram í breiðu samstarfi fjölmargra aðila. Adgerðirnar purfa til dæmis að beinast að sköpun nýrrar pekkingar, próun nýrra lausna sem byggjast á tækni eða pjónustu

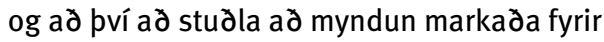
nýjar lausnir.

Opinberir aðilar geta skapad grundvöll fyrir samstarfi yfir landamæri sem getur leitt til nýstárlegra lausna og pannig ýtt undir breytingaferli. Í pessu sambandi er mikilvægt að atvinnulífið og opinberi geirinn ræðist stöðugt við. Ef ýta á undir nýsköpun er jafnframt mikilvægt að vinna með opið skipulag par sem bæði konur og karlar, fólk med mismunandi bakgrunn og ungir jafnt sem eldri geta tekið pátt. Hugmyndir, pekking og kunnátta peirra sem hafa langa starfsreynslu verður sífellt mikilvægari audlind. Sköpunarkrafturinn er mikilvægur páttur í nýsköpunarferlinu og hann verður meiri í hópum par sem jafnrétti ríkir. Karlmenn og konur eiga að hafa sömu tækifæri til að nýta kunnáttu sína, hafa áhrif og fá aðgang ad aðföngum.

Nýsköpunarkraftur norrænu ríkjanna kemur nú pegar vel út í alpjódlegum

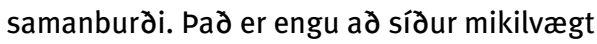
fyrir hvert land að halda áfram að efla nýsköpunarumhverfið og endurnýjunarkraft atvinnulífsins til pess að hagvöxturinn verði sjálfbær. Pað gildir meðal annars um greinar sem eru nátengdar loftslagsbreytingum, skilvirkri nýtingu audlinda og lýðfræðilegri próun.

Vegna pess hversu stór og flókin verkefnin eru og vegna pess à oft eru pau sameiginleg öllum norrænu ríkjunum getum við haft gagn af auknu samstarfi um að finna pær lausnir sem pörf er á. Norðurlönd hafa 
gódar forsendur til að efla samstarf sitt á ýmsum svidum nýsköpunar og atvinnulífs pannig að pau geti tekist á við framtídina. pessi samstarfstækifæri norrænu ríkjanna byggja á pví við höfum að miklu leyti sömu gildi og erum sterk á sömu sviðum. Hefə̀ er fyrir gagnsæi, aðgengi, jafnrétti og réttaröryggi. Samfélagsgerðin og velferðarkerfin eru svipuð og koma vel út í alpjódlegum samanburði. Í norrænu löndunum er einnig a finna mörg mikilvæg hráefni og náttúruaudlindir og jafnframt hápróaðan úrvinnsluiðnað og verðmæti sem fólgin eru í einstökum loftslagsskilyrðum. Löndin standa nú öll tiltölulega framarlega hvað varðar stafræna samfélagspróun. Við erum jafnframt í fremstu röd i starfi okkar að ýmsum umhverfismálum. Annað sem einkennir löndin er að pau eru tiltölulega strjálbýl, heimamarkaðirnir eru litlir og pörfin fyrir umheiminn mikil. Sá munur sem er á löndunum getur einnig orðið tækifæri til að skiptast á reynslu og læra hvort af öəru.

\section{Virðisaukinn af norrænu samstarfi}

Norðurlönd eru ellefta stærsta hagkerfi heims og í sameiningu verður rödd okkar sterkari á albjódavettvangi. Virðisaukinn af norrænu samstarfsemi er fólginn í mörgum mismunandi páttum. Meə pví ad̀ starfa saman eykst vægi okkar á alpjódavettvangi. Við getum skipst á reynslu og pekkingu. Við getum deilt kostnaði sem tengist pekkingarframleiðslu, innviðum og gagnaöflun. Við getum tekist á við vanda sem nær til fleiri en eins lands, fundið sameiginlegar lausnir og próad sameiginlegan grundvöll fyrir norræn fyrirtæki og opinbera adila. Gott samstarf getur komið okkur öllum að gagni; Norðurlöndum sem svæði, fyrirtækjunum par og íbúunum. 


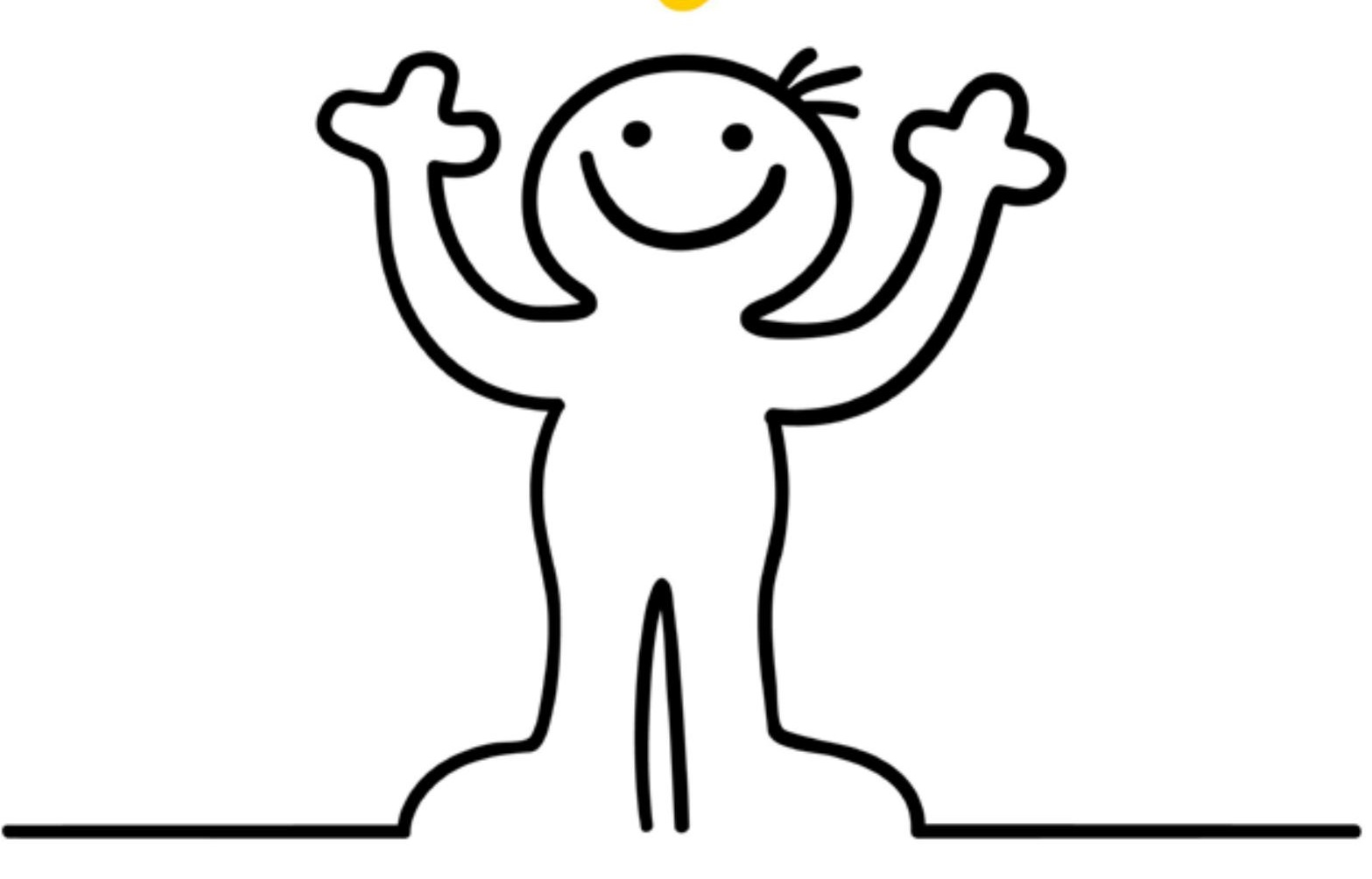




\section{ÁHERSLUR İ SAMSTARFINU 2014-2017}

Haustið 2010 sampykktu atvinnumálarádherrar Norðurlanda nýja samstarfsáætlun í nýsköpunar- og atvinnumálum fyrir tímabilið 2011-2013. Sex kyndilverkefni voru unnin á áherslusvidunum nýsköpun, frumkvödlastarf, grænn hagvöxtur og velferð. Áherslurnar í nýju norrænu samstarfsáætluninni fyrir tímabilið 20142017 byggja á reynslunni og peim góda árangri sem nádist við framkvæmd fyrri samstarfsáætlunarinnar.

Við gerð nýju samstarfsáætlunarinnar hafa farið fram samræður milli norrænu ríkjanna og fulltrúa atvinnulífsins og opinberra aðila. pað hefur leitt til pess að ýmis mál sem eru mikilvæg fyrir stefnu Norðurlanda í nýsköpunar- og atvinnulífsmálum hafa hlotið aukið vægi.

Nýja samstarfsáætlunin í nýsköpunar- og atvinnulífsmálum 2014-2017 skiptist í fjögur pemu sem öll byggjast á ýmsum skilgreindum áskorunum. Pemun eru:

- Frumkvödlastarf og fjármögnun

- Grænn hagvöxtur

- Nýjar velferdarlausnir

- Menning og skapandi greinar í págu hagvaxtar

Pemun íáætluninni eru breið og í peim felast ýmsar áskoranir. Innan ramma pemanna eru kynnt til sögunnar svoköllua kyndilverkefni. Gerð er sú krafa til pess starfs sem fer fram undir hverju kyndilverkefni ad búast megi við pví árangurinn verði meiri en ella vegna pess að Norðurlöndin starfi saman að verkinu. Hluti af peim verkum sem unnin eru í tengslum við kyndilverkefnin felast einkum

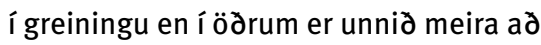
framkvæmd.

Í samstarfsáætluninni er einungis fjallà stuttlega um áherslurnar í kyndilverkefnunum. Kyndilverkefnin verða skilgreind nánar með pví að gera forkannanir og í verkefnalýsingunum sem pátttakendur í verkefnunum semja.

Í samstarfsáætluninni kemur fram hvada verkefni verda unnin ad lágmarki á sviði stefnumótunar í nýsköpunar-og atvinnumálum á Norðurlöndum á tímabilinu 2014-2017. Unnið verður að ýmsum öərum verkefnum og starfsemi samhliða kyndilverkefnunum á vettvangi norræns samstarf um stefnumótun í nýsköpunarog atvinnulífsmálum. Nordmin er stórt verkefni af pessu tagi. Pad er svonefnt sérfræðinetverk (Network of Expertise) og á meðal annars að efla samkeppnishæfni norræna námu- og málmiðnadarins og vekja athygli á mikilvægi atvinnugreinarinnar fyrir grænan hagvöxt á Norðurlöndum og í Evrópu. 


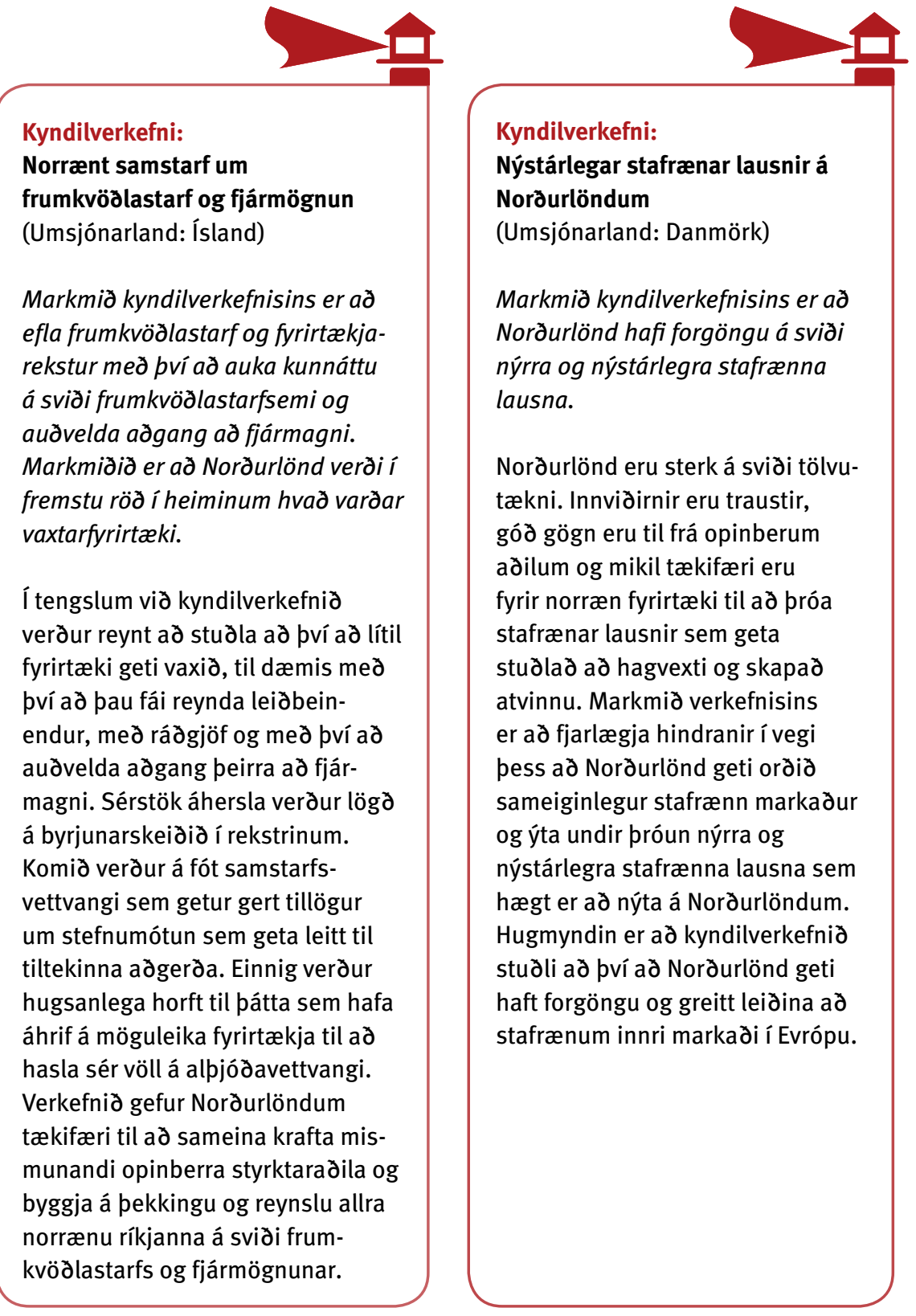




\section{PEMU OG KYNDILVERKEFNI}

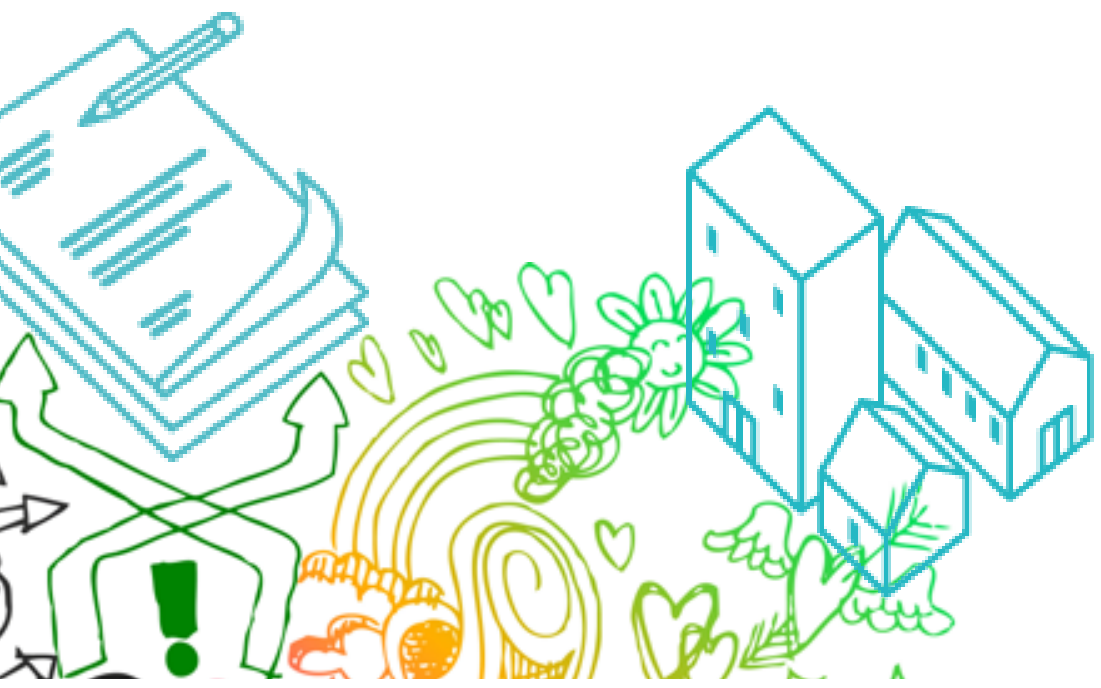

\section{Grænn hagvöxtur}

Metnaðarfull markmið Norðurlanda í umhverfismálum geta ýtt undir nýsköpun. Aдgerðir sem miða að grænum hagvexti snúast ekki bara um próun nýrrar tækni og orkumál heldur einnig aðrar snjallar lausnir og pjónustu sem nýtir audlindir med skilvirkum hætti.

Hugtakið grænn hagvöxtur hefur fest sig í sessi og sterkur pólitískur vilji er fyrir pví að atvinnulífið próist í pessa átt. Mikilvæg forsenda fyrir grænum og sjálfbærum hagvexti er að til verði markaðir par sem eftirspurn er eftir lausnum af pessu tagi. Opinberir adilar geta gegnt lykilhlutverki í pessu sambandi med forgangsrödun, pöntunum og med pví ad búa í haginn fyrir grænan hagvöxt á mörgum sviðum.

Norðurlönd geta starfað saman að grænum hagvexti á margan hátt. Útflutningur er til dæmis mikilvægur páttur en hvert um sig geta löndin átt erfitt með að búa til samhæfдar og markadsvænar „kerfislausnir“. Norrænir adilar geta styrkt samkeppnisstödu sína med pví ad starfa saman undir einu norrænu vörumerki, meðal annars á mörkuðum utan Norðurlanda.

Kyndilverkefnið Nordic Built var sett af stad innan ramma norrænu samstarfsáætlunarinnar um stefnumótun í nýsköpunar- og atvinnumálum fyrir tímabilið 2011-2013. Markmiðið var meðal annars að ýta undir próun samkeppnishæfra norrænna lausna fyrir loftslagsvænan og orkunýtinn byggingaridnad. Pess vegna er nú til samstarfsvettvangur sem hefur fest sig í sessi og sem skapar gód skilyrdi fyrir pví ad halda áfram ad̀ vinna ad málum sem snerta grænan hagvöxt. 


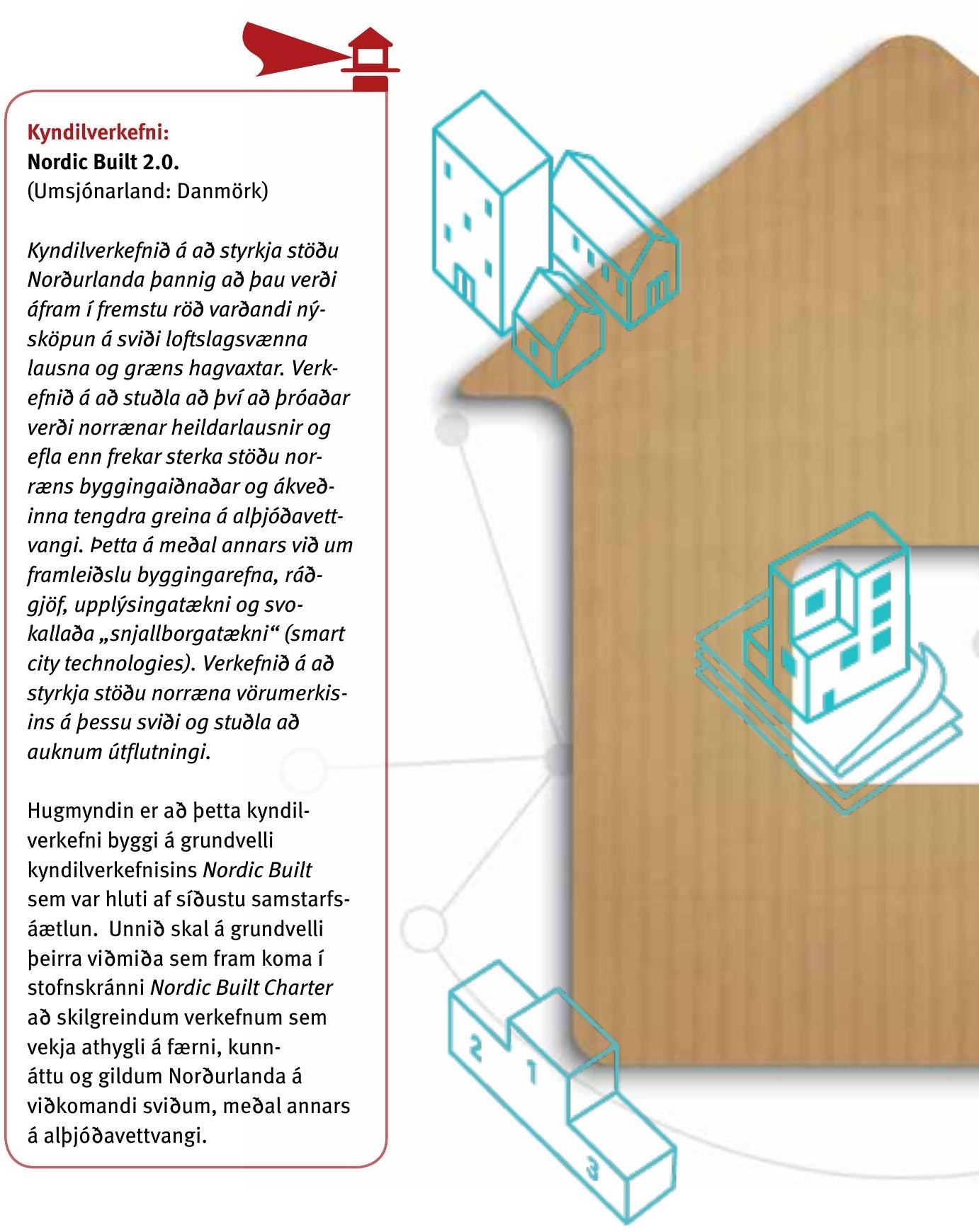




\section{PEMU OG KYNDILVERKEFNI}

\section{Nýjar velferðarlausnir}

Miklar lýdfræðilegar breytingar eru að̀ verða um pessar mundir í öllum norrænu ríkjunum. Breytingarnar valda álagi á velferðarkerfin sem byggdust upp á 20. öld og kalla á endurskodun peirra. Nútímavæða parf pau kerfi sem fyrir eru til pess að pau rádi við breyttar lýdræðilegar aðstæður. padá við um allt frá dagvistun barna, menntun, atvinnumiðlun og tryggingakerfum til heilbrigðispjónustu og umönnunar aldraðra.

\section{Notendur pjónustunnar gera síauknar} kröfur og velferðarkerfin purfa pess vegna stöðugt að takast á við ný verkefni og taka framförum. Pörf er á nýjum lausnum á öllum sviðum heilbrigðiskerfisins til pess að hægt sé ad bjóda upp á skilvirka og góda samfélagspjónustu.

Pær áskoranir sem velferðarkerfið stendur frammi fyrir eru að nokkru leyti alpjódlegar.
Finna má ákveðna sameiginlega pætti sem sérkenna norrænu ríkin, meðal annars í tengslum við aldurssamsetninguna. Eitt mikilvægt svið par sem unnið er að próun velferðarlausna í öllum norrænu ríkjunum er heilsa, heilbrigðispjónusta og umönnun. Vegna pess að heilbrigðiskerfið er að stærstum hluta fjármagnað með opinberu fé getur opinberi geirinn ýtt undir nýsköpun með opinberum innkaupum, með pví að styðja við ný viðskiptalíkön og með pví að halda áfram ad fjárfesta i rannsóknum og próun.

Með norrænu samstarfi par sem áhersla er lögðá tiltekin málefni á sviði heilbrigðis, heilbrigðispjónustu og umönnunar er hægt aə skapa grundvöll fyrir öflun nýrrar pekkingar og nýrra viðskiptalausna sem hægt er að hrinda i framkvæmd í hverju landi fyrir sig.

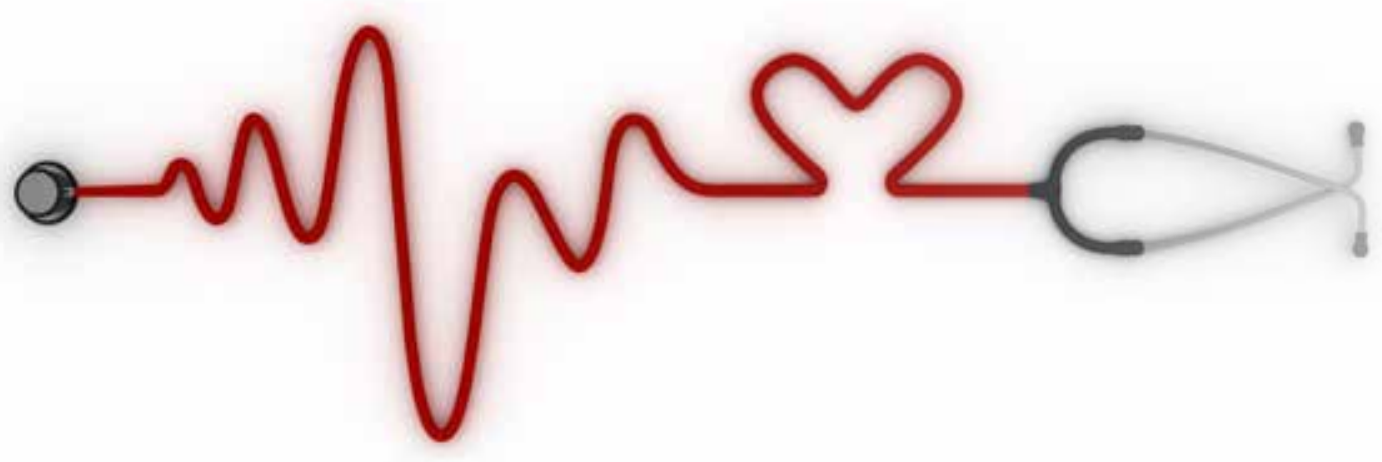




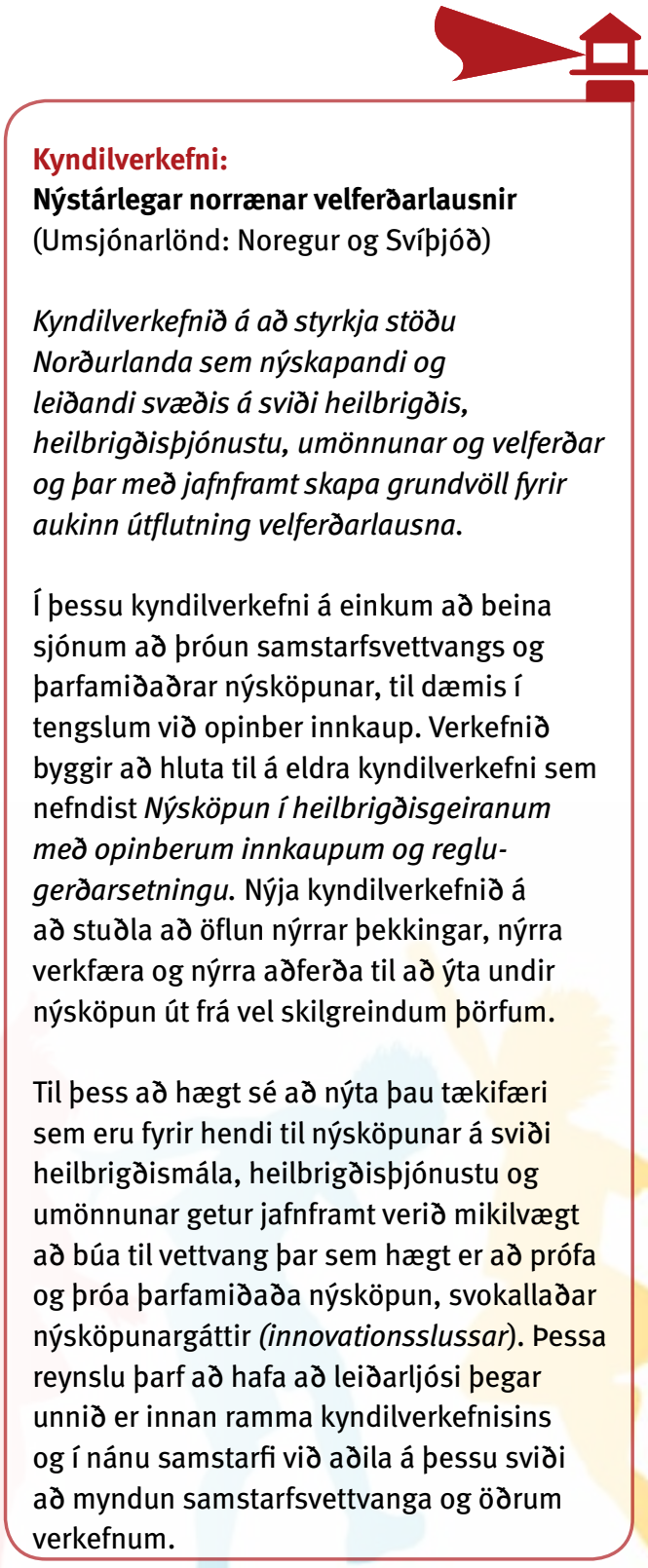
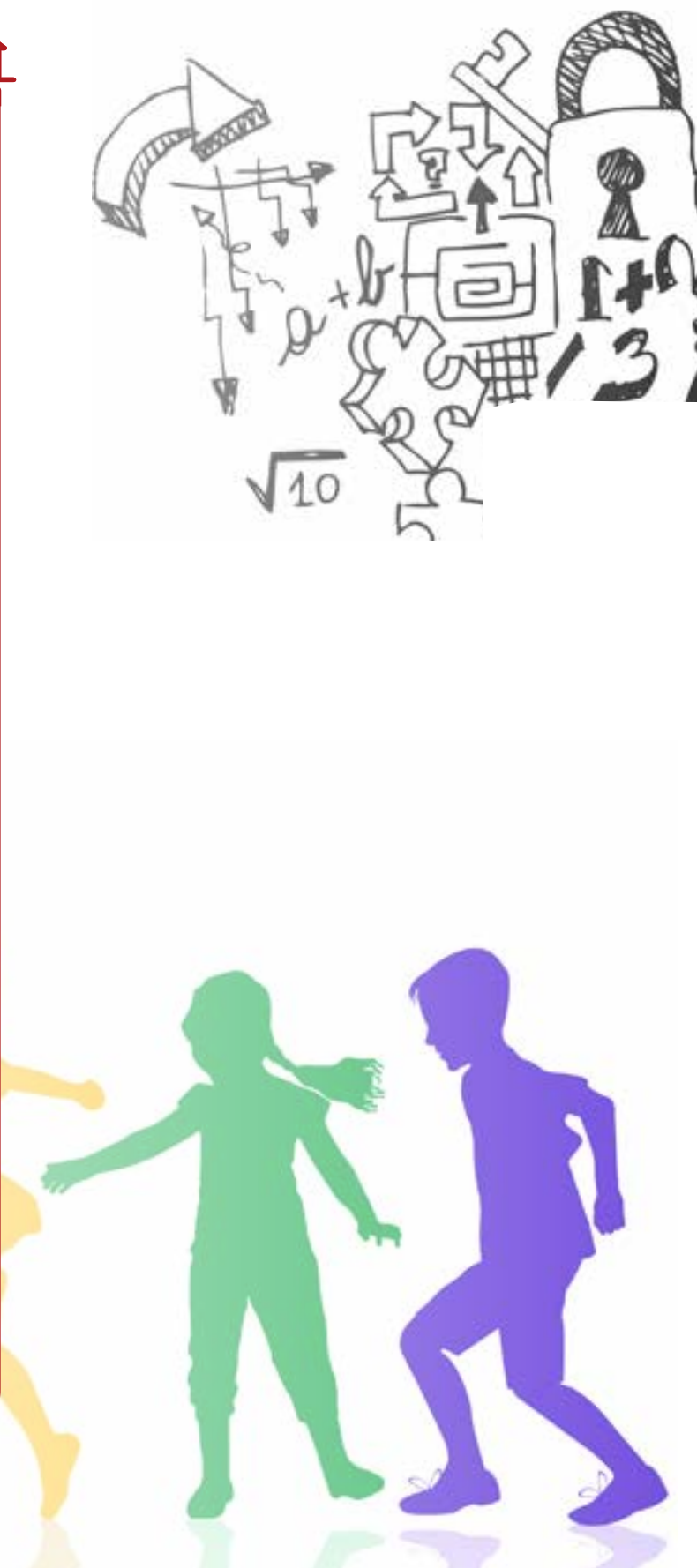


\section{PEMU OG KYNDILVERKEFNI}

\section{Menning og sköpun í págu hagvaxtar}

Við stefnumótun í atvinnumálum hefur sífellt meiri athygli verið beint að menningartengdum og skapandi greinum. Padá medal annars við um fyrirtæki sem selja vörur eda veita pjónustu sem tengist hönnun, tísku, kvikmyndum, tónlist, bókmenntum, tölvuleikjum og svo framvegis. Á vettvangi norræns samstarfs hefur KreaNord unnið að pví sídan 2008 ad efla menningartengdar og skapandi greinar (sjá www.kreanord.org). Pað er pví pegar til norrænn grundvöllur sem hægt er ad byggja á. Hugmyndin er ad pad

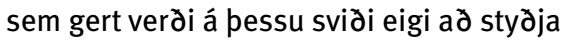
við og skila auknum norrænum virðisauka til viðbótar pví starfi sem KreaNord vinnur.

Menningartengdar og skapandi atvinnugreinar stuðla að auknum hagvexti og vaxa nú pegar hradar en margar aðrar atvinnugreinar innan Evrópusambandsins. Eftirspurn eftir vörum, pjónustu og pekkingu úr pessum geira atvinnulífsins eykst bæði á Norðurlöndum og á alpjódavettvangi, sérstaklega í nýjum og vaxandi hagkerfum Í BRIC og NEXT11 par sem millistéttin vex. pjónusta verdur sífellt meira rádandi í hagkerfinu og pjónustan tengist í síauknum mæli óefnislegum fjárfestingum og óefnislegu fjármagni fyrirtækja, par á medal pekkingu, hönnun og vörumerkjum. Pess

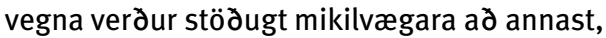
standa vörd um og próa óefnislegar eignir.

\footnotetext{
Á Norðurlöndum er til hæfileikafólk og nýsköpunarkjarnar á mörgum sviðum innan menningartengdra og skapandi greina sem njóta viðurkenningar vída um heim.
}

Tengingin við Norðurlönd er ein helsta ástæða pess að eftirspurn er eftir vörum og pjónustu frá menningartengdum og skapandi greinum. Margir tengja „norræna vörumerkið“ við gædi og aðra jákvæða eiginleika. Aukin sala og aukinn sýnileiki menningartengdra og skapandi greina á Norðurlöndum á alpjódavettvangi getur jafnframt leitt til aukins áhuga á Norðurlöndum sem svæði. pad getur haft jákvædá adrar atvinnugreinar, til dæmis móttöku ferdamanna og upplifunarferdamennsku. Hægt er að efla nýsköpun og samstarf um ferðamennsku og upplifunariðnad á Norðurlöndum og vinna

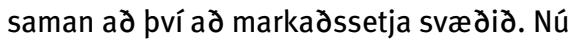
pegar er unnið ad ýmsum verkefnum á sviði ferdamanna- og upplifunariðnaðarins og markadssetningar í hverju landi fyrir sig. Pessi verkefni væri hægt að próa frekar og bæta á norrænum vettvangi til pess ad gera pau alpjódlegri og öflugri, medal annars á nýjum, vaxandi mörkuðum.

Menningartengdar og skapandi greinar geta komið með nýstárlegar hugmyndir

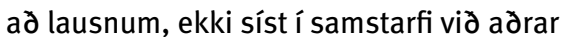
greinar atvinnulífsins. Víxlverkun og aukid samstarf menningartengdra og skapandi greina við aðrar atvinnugreinar getur skilad sér í nýjum vörum og pjónustu, oft med peim árangri að fagurfræðilegt, félagslegt eða umhverfislegt gildi vörunnar eða pjónustunnar eykst. Petta getur opnad aðgang að nýjum mörkuðum, orðið öðrum greinum atvinnulífsins til framdráttar og stuðlad að aukinni samkeppnishæfni norrænna fyrirtækja. 


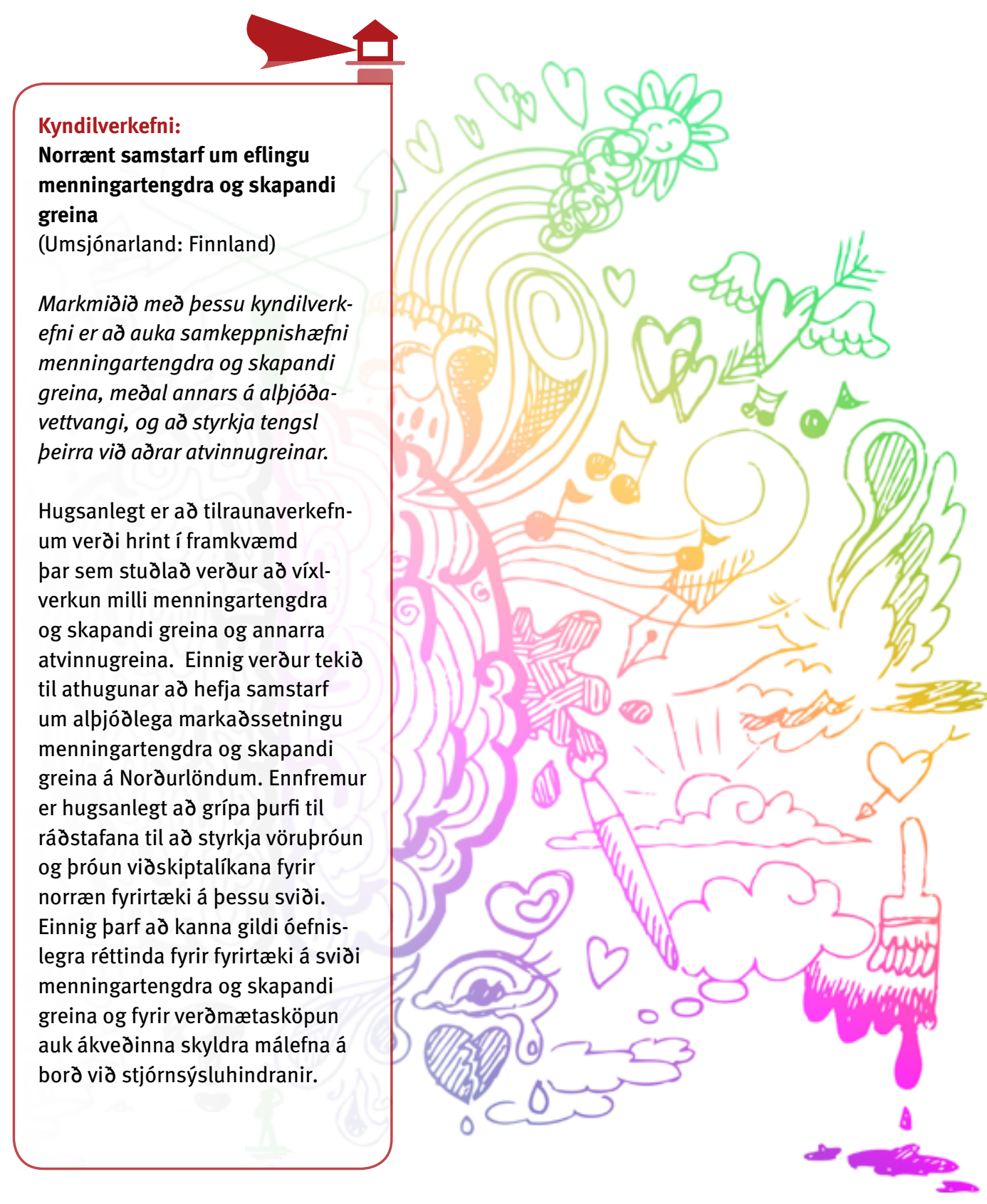




\section{PEMU OG KYNDILVERKEFNI}

\section{Framkvæmd, fjármögnun og eftirfylgni kyndilverkefnanna}

Umsjónarlönd hvers kyndilverkefnis taka ad sér ad ýta á eftir starfinu og leiða pad í samstarfi við aðra adila sem vinna ad verkefninu. Ætlast er til að öll norrænu ríkin taki virkan pátt í öllum kyndilverkefnunum. Pó getur verið mismunandi milli kyndilverkefna hvaða adilar taka pátt í starfinu. Samstarfið milli ríkjanna og ýmissa samstarfsaðila getur ennfremur verið med ólíkum hætti í mismunandi kyndilverkefnum. Mikilvægt er að pað starf sem verður unnið byggi á traustum grunni og njóti stuðnings í öllum norrænu ríkjunum. Ennfremur er mikilvægt að verkefnin komi öllum norrænu ríkjunum aə̀ notum. Einnig skiptir máli ad virkja atvinnulífið í framkvæmd kyndilverkefnanna, bæði á byrjunarskeiði og ítrekad á sídari stigum. Norrænir aðilar sem málið snertir eiga ad nýta pekkingu sína, tengslanet og greiningar til að aðstoða við framkvæmd verkefnanna.

Norræna nýsköpunarmiðstöðin, sem heyrir undir Norrænu rádherranefndina og Embættismannanefndina um atvinnulíf, gegnir lykilhlutverki við framkvæmd samstarfsáætlunarinnar og mun aðstoda við stefnumótun og umsýslu kyndilverkefnanna. Norræna nýsköpunarmiðstöðin vinnur medal annars að pví að efla frumkvöðlastarf, viðskipti og nýsköpun sem fram fer á Norðurlöndum eda á uppruna sinn par. Norræna nýsköpunarmiðstöðin stuðlar að auknum samskiptum milli opinbera geirans og einkageirans og vinnur að verkefnum sem skapa norrænan virðisauka með samstarfi milli landanna.

Embættismannanefndin um atvinnulíf hefur veitt samtals eina milljón danskra króna til að hrinda kyndilverkefnunum af stað. Afgangurinn af fjármögnun peirra getur komið frá Norrænu nýsköpunarmiðstöðinni, af pví fé sem Embættismannanefndin um atvinnulíf hefur til verkefnastyrkja og frá ödrum fjármögnunaraðilum sem tengjast Norrænu rádherranefndinni eda sem viðbótarfjármögnun frá yfirvöldum i einstökum löndum, samtökum eda fyrirtækjum.

Umsjónaraðilar kyndilverkefnanna eiga ad skila árlegri skýrslu um framvindu peirra til atvinnumálarádherra Norðurlanda. Embættismannanefndin um atvinnulíf getur ennfremur ákveðid ad láta fara fram úttekt á kyndilverkefnunum pegar pau verda hálfnud í lok árs 2015.

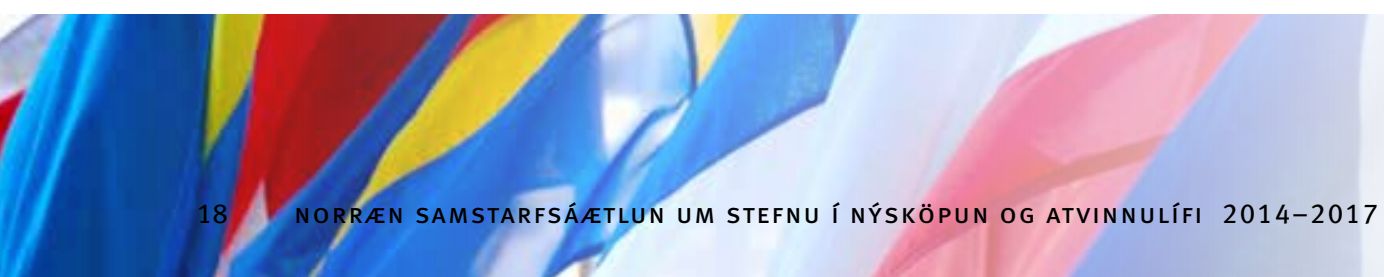





\section{norden}

Norræna rádherranefndin

Ved Stranden 18

DK-1061 Copenhagen K

www.norden.org

\section{Norræn samstarfsáætlun um stefnu í nýsköpun og atvinnulífi 2014-2017}

Norrænu pjódirnar hafa lengi unnið saman. Samstarfid byggir á sameiginlegum gildum og ósk um að ná árangri sem stuðlar að öflugri próun svæðisins. Medal markmiðanna er að eftirsóknarvert verði að búa, starfa og reka fyrirtæki á Norðurlöndum og ad efla samkeppnishæfni norrænu ríkjanna á alpjódavettvangi.

Leidarljós norrænu samstarfsáætlunarinnar um stefnumótun í nýsköpun og atvinnulífi er að reyna að takast á við nokkur af peim verkefnum sem blasa við Norðurlöndum î framtídinni. 